\title{
Studies on the Freezing of Red Spanish and Smooth Cayenne Pineapples ${ }^{1}$
}

\author{
F. Sánchez Nieva and I. Hernández ${ }^{2}$
}

\begin{abstract}
Slices of Red Spanish and Smooth Cayenne pineapples vacuum packed in plastic bags without sirup developed strong off flavors during storage at $-10^{\circ}$ $\mathrm{F}\left(-23.3^{\circ} \mathrm{C}\right)$ even though the bromelin and the peroxidases were inactivated by blanching. Red Spanish slices frozen in sirup with 100 to $300 \mathrm{mg}$ of ascorbic acid/lb of pack retained their original quality without developing appreciable off flavors when stored at $-10^{\circ} \mathrm{F}$ for about 280 days. When the slices were packed in sirup, blanching to inactivate the peroxidases and the bromelin improved slightly both quality and shelf life of the frozen product. The quality of the frozen slices, however, was low and sometimes inferior to the canned product.
\end{abstract}

\section{INTRODUCTION}

The literature $(3,6)$ indicates that when Cuban and Puerto Rican Red Spanish pineapple is frozen, off flavors sometimes develop during storage. Processing characteristics of crops are influenced by varietal characteristics, cultural practices, ecological factors, condition of the harvested product, and handling and storage before processing.

No formal studies have been conducted to determine the freezing characteristics of locally produced fresh pineapples. Therefore, it was felt desirable to determine the freezing potential of locally-produced fresh-processed pineapple.

This paper reports studies on the freezing of fresh Red Spanish and Smooth Cayenne pineapple, including the effect of several processing variables on the quality and shelf life of the frozen product.

\section{MATERIALS AND METHODS}

The fruit for these studies was obtained from commercial plantations of the Land Authority of Puerto Rico. Unless otherwise indicated, the fruit was harvested at the three-quarter ripe stage.

The fruit was cylindered and cored in an Elliot sizer and corer. ${ }^{3}$ The cylinders were sliced in an F.M.C. slicer or by hand into slices approximately 0.5 in $(1.27 \mathrm{~cm})$ thick.

${ }^{1}$ Manuscript submitted to the Editorial Board January 12, 1977.

${ }^{2}$ Chemical Engineer and former Assistant Chemical Engineer, Food Technology Laboratory, Agricultural Experiment Station, Mayagüez Campus, University of Puerto Rico, Río Piedras, P.R.

${ }^{3}$ Trade names are used in this publication solely for the purpose of providing specific information. Mention of a trade name does not constitute a guarantee or warranty of equipment or materials by the Agricultural Experiment Station of the University of Puerto Rico or an endorsement over other equipment or materials not mentioned. 
The slices were blanched as follows: 1) steam blanching-heating in steam atmosphere at atmospheric pressure in a drapper blancher; and 2) heating in a kettle in sirup of the concentration being tested to $195^{\circ} \mathrm{F}$ $\left(90.5^{\circ} \mathrm{C}\right)$. In both methods, the fruit was blanched for the time required to inactivate the bromelin, as indicated by a negative milk clotting test (1), or to inactivate the peroxidases, as indicated by a negative guaiacol$\mathrm{H}_{2} \mathrm{O}_{2}$ test (6).

When no sirup was added, the slices were vacuum-packed in Cryovac bags. When sirup was added, the slices were packed in boilable pouches or in aluminum foil cups. Sirup of the desired concentration was added to cover the slices.

In the experiments in which ascorbic acid was added as antioxidant, the acid was dissolved in the sirup at levels corresponding to 100,200 , 300 and $400 \mathrm{mg} / \mathrm{lb}$ of product $(220,440,660$ and $880 \mathrm{mg} / \mathrm{kg})$.

Irrespective of the type of package used, the fruit was frozen at $-40^{\circ} \mathrm{F}$ $\left(-40^{\circ} \mathrm{C}\right)$ in a plate freezer and stored at $-10^{\circ} \mathrm{F}\left(-23.3^{\circ} \mathrm{C}\right)$ until used.

Soluble solids (Brix) were determined on juice squeezed from the pulp with a refractometer. Reducing and total sugars were determined by the AOAC Lane and Eynon volumetric method (4). Acidity and $\mathrm{pH}$ were measured by the AOAC glass electrode method (4). Moisture was determined by the vacuum oven method (4). Ascorbic acid was determined by the method of Ballantine (2).

For sensory tests the fruit was thawed overnight in a refrigerator, except when boilable bags were used. To thaw the product packed in the boilable pouches, the pouches were immersed in hot water until the slices were completely thawed.

Rating scales were used for judging sample quality and off-flavor intensity. When rating for sample quality a 6-point scale was used, ranging from 6 -like very much, to 1 -dislike. For off-flavor intensity a 5 -point scale was used, ranging from 5-no detectable off flavors, to 1strong off flavors.

Results of the sensory tests were analyzed for significance by the $t$ or $F$ tests (5).

\section{RESULTS AND DISCUSSION}

It has been suggested that the change in flavor in frozen pineapple may be due to the action of proteolytic enzymes $(2,6)$. Therefore, the effect of blanching treatments on the chemical composition and flavor was investigated first.

Table 1 shows the effect of blanching treatments on the chemical composition of frozen slices of the Red Spanish and Smooth Cayenne varieties. Two blanching treatments were tested: 1) Blanching in steam until the bromelin was inactivated, as indicated by a negative milk 
clotting test; and 2) blanching in steam to inactivate the peroxidases, as indicated by a negative guaiacol-hydrogen peroxide test. A 2-min heating in steam at atmospheric pressure was required to inactivate the bromelin, and $3 \mathrm{~min}$ to inactivate the peroxidases. For both varieties unblanched controls were included in the test.

Neither variety changed in $\mathrm{pH}$. In the Red Spanish samples the total acidity was reduced by blanching, the greater loss taking place in the sample with a longer blanching period. No such change took place in the Smooth Cayenne samples. In both varieties a slight reduction in Brix values (soluble solids) and a reduction in total sugars resulted during blanching, which indicates loss of juice during heating. Both controls had a higher reducing sugar content than the blanched samples, suggesting the presence of an invertase which was not inactivated by heat. In both varieties, blanching resulted in a considerable loss of ascorbic acid, which increased in proportion to the length of the blanching treatment.

TABLE 1. -Effect of blanching treatments on the chemical composition of frozen Red Spanish and Smooth Cayenne pineapple slices

\begin{tabular}{|c|c|c|c|c|c|c|c|}
\hline Blanching treatment & $\mathrm{pH}$ & $\begin{array}{c}\text { Total } \\
\text { acidity } \\
\text { as anhy- } \\
\text { drous } \\
\text { citric } \\
\text { acid }\end{array}$ & Moisture & ${ }^{\circ}$ Brix & $\begin{array}{l}\text { Total } \\
\text { sugars as } \\
\text { invert }\end{array}$ & $\begin{array}{l}\text { Reduc- } \\
\text { ing } \\
\text { sugars }\end{array}$ & $\underset{\mathrm{C}}{\operatorname{Vitamin}}$ \\
\hline & & $\%$ & $\%$ & & $\%$ & $\%$ & $\mathrm{mg} / 100 \mathrm{~g}$ \\
\hline \multicolumn{8}{|c|}{ Red Spanish } \\
\hline None & 3.50 & 0.70 & 83.30 & 16.0 & 15.31 & 7.60 & 37.23 \\
\hline Bromelin inactivated & 3.54 & .51 & 84.94 & 14.2 & 12.75 & 3.48 & 36.68 \\
\hline Peroxidases inactivated & 3.58 & .48 & 83.37 & 15.0 & 13.39 & 3.91 & 15.94 \\
\hline \multicolumn{8}{|c|}{ Smooth Cayenne } \\
\hline None & 3.80 & .35 & 82.20 & 15.8 & 14.94 & 8.98 & 12.81 \\
\hline Bromelin inactivated & 3.86 & .39 & 83.35 & 14.0 & 13.78 & 3.70 & 11.17 \\
\hline Peroxidases inactivated & 3.78 & .38 & 83.15 & 14.8 & 14.00 & 3.80 & 8.38 \\
\hline
\end{tabular}

Table 2 summarizes the results of organoleptic tests in which controls and blanched samples were rated for overall sample quality and offflavor intensity after storage for 75 and 184 days.

The results of the tests with the Red Spanish pineapple after 75 days of storage show that sample quality was reduced by the blanching treatment needed to inactivate the peroxidases. A significant difference at $1 \%$ probability level was found between the peroxidase inactivated sample and the bromelin inactivated and the control. No significant difference was found between the control and the bromelin inactivated samples.

In the case of the Smooth Cayenne, the sample with the bromelin inactivated was found superior in quality to the control at the 5\% probability level, but similar in quality to the control. 
Heating Red Spanish slices to inactivate the peroxidases caused off flavors; the differences in the scores among this sample, the control, and the bromelin-inactivated sample being significant at the $1 \%$ probability level. Differences for off-flavor intensity were not significant among the Smooth Cayenne samples.

No significant changes in overall sample quality and off-flavor intensity took place in the unblanched controls of either Red Spanish or Smooth Cayenne slices during their storage at $-10^{\circ} \mathrm{F}\left(-23.3^{\circ} \mathrm{C}\right)$ for 184 days. However, quality decreased markedly and off-flavor intensity increased in the blanched samples of both varieties. Since in both varieties the bromelin and peroxidases were inactivated by the heat treatment, the change in flavor during storage cannot be attributed to the action of these enzymes. Smooth Cayenne received higher ratings than Red Spanish.

It was impossible to determine at a known level of probability the

TABLE 2.-Effect of blanching treatments on sample quality and shelf life in frozen Red Spanish and Smooth Cayenne pineapple slices

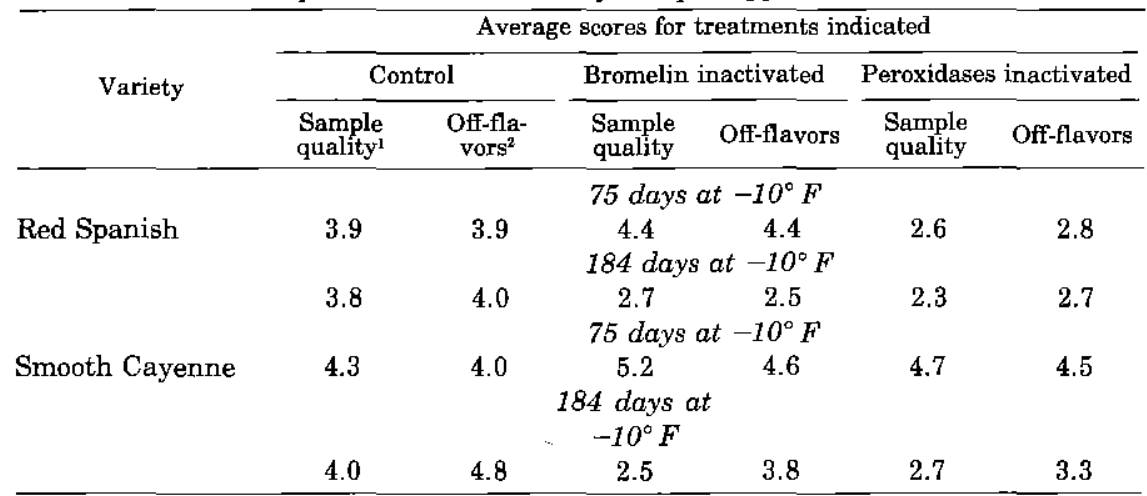

${ }^{1}$ Sample quality -6 , like very much, 1 dislike.

${ }^{2}$ Off-flavors -5 , no detectable off-flavors -1 , Strong off-flavors

effect of blanching on texture due to the diversity of opinions among tasters in regard to the fibrousness of the blanched slices. Texture measurements with the shear press indicated that blanched slices generally had a time-force curve with a higher peak than unblanched samples, which suggests an increase in fibrousness during blanching. This apparent increase in fibrousness may be caused by leaching of the juice during the blanching treatment with the result that the slices become less jucy and succulent. This loss of juice and increase in fibrousness during blanching may explain in part the decrease in quality resulting from the blanching treatments.

Table 3 shows the effect of blanching treatments on the quality and shelf life of Red Spanish slices packed in 20, 30 and 40 Brix sugar sirups. 
In this table it is possible to compare the effect of blanching treatments for one concentration and the effect of sirup concentration for each blanching treatment.

In samples without blanching, overall quality increased as the sirup concentration increased from 20 to 40 Brix after the two storage periods indicated. This trend was not observed in any of the blanched samples. Sirup concentration had no effect on off flavors.

When the overall quality is compared for the effect of the blanching treatments after 75 days in storage, the three concentration scores decreased as the length of the blanching treatment increased. No significant change in quality or off-flavor intensity was found in the unblanched control after 231 days. Quality ratings were higher for the blanched samples with no indications of increased off-flavor intensity.

In another series of experiments, where slices blanched in steam for 4 min were compared with unblanched controls, when packed in sirup of

TABLE 3.-Effect of blanching treatment and packing medium on the scores of quality of frozen slices of Red Spanish pineapple for different storage periods (days)

\begin{tabular}{|c|c|c|c|c|c|c|}
\hline \multirow[t]{2}{*}{ Packing medium } & \multicolumn{2}{|c|}{ Control-no blanching } & \multicolumn{2}{|c|}{ Bromelin inactivated } & \multicolumn{2}{|c|}{ Peroxidases inactivated } \\
\hline & \multicolumn{6}{|c|}{ Sample quality after storage at $-10^{\circ} \mathrm{F}$} \\
\hline Days & 75 & 231 & 75 & 234 & 75 & 237 \\
\hline $20^{\circ}$ Brix & 3.9 & 4.3 & 3.6 & 4.2 & 3.1 & 4.6 \\
\hline $30^{\circ}$ Brix & 4.6 & 4.4 & 3.0 & 4.0 & 3.7 & 4.7 \\
\hline \multirow[t]{2}{*}{$40^{\circ}$ Brix } & 4.7 & 5.0 & 3.6 & 4.0 & 3.1 & 4.1 \\
\hline & \multicolumn{6}{|c|}{ Off-flavor intensity after storage at $-10^{\circ} \mathrm{F}$} \\
\hline Days & 75 & 231 & 75 & 234 & 75 & 237 \\
\hline $20^{\circ}$ Brix & 4.0 & 3.9 & 4.2 & 4.4 & 3.9 & 4.3 \\
\hline $30^{\circ}$ Brix & 4.4 & 4.2 & 3.6 & 4.0 & 3.6 & 4.7 \\
\hline $40^{\circ}$ Brix & 4.5 & 4.3 & 4.3 & 4.2 & 3.7 & 4.5 \\
\hline
\end{tabular}

20,35 , and 50 Brix for overall quality, the following results were obtained:

Sirup concentration

Brix
20
35
50

Scores in a 5-point scale Unblanched

2.2

3.1

2.5
Blanched

2.4

3.6

3.1

This confirms previous findings that when the slices are packed in sirup the quality is sometimes improved by blanching.

In other experiments, instead of blanching the slices in steam they were blanched by heating for 5 minutes in 30 Brix sirup and packed in fresh chilled 30 Brix sirup. The results of these experiments also showed that when the slices are packed in sirup, blanching improved quality.

Table 4 shows the effect of adding different levels of ascorbic acid on the shelf life of unblanched Red Spanish slices packed in 30 Brix sirup. 
After a storage period of 231 days, all samples with ascorbic acid added to the levels indicated received higher ratings for overall quality than the control. Addition of ascorbic acid to a level of $400 \mathrm{mg} / \mathrm{lb}$ prevented the development of off flavors during storage. This sample scored 5 for off-flavor intensity, which indicates that none of the tasters found any off flavors.

In the course of this work, which lasted several growing seasons, samples processed alike often differed greatly in quality. Some of them were rated fairly low in quality by the taste panel. Since the rating was made shortly after freezing, the low quality cannot be attributed to changes during storage nor to treatment effects. This suggests that the low quality of the frozen samples could be due to changes in fruit quality caused by cultural practices or ecological conditions rather than to a varietal characteristic. Further studies are necessary to clarify this point.

In other experiments comparing frozen slices with canned samples from the same lot or with commercially canned product, the frozen sam-

TABLE 4. -Effect of different levels of ascorbic acid on sample quality and off-flavor intensity in unblanched frozen slices of Red Spanish pineapple stored at $-10^{\circ}$ Brix for 231 days

\begin{tabular}{ccc}
\hline Level of ascorbic acid & Sample quality & Off-flavor intensity \\
\hline$m g / l b$ & 6 -point scale & 5 -point scale \\
0 & 4.1 & 4.1 \\
100 & 4.6 & 4.3 \\
200 & 4.9 & 4.3 \\
300 & 4.7 & 4.3 \\
400 & 4.6 & 5.0 \\
\hline
\end{tabular}

ples were found either equal in quality to the canned or slightly inferior, but never better.

Due to the wide variation in the quality of the experimental lots, the results of this work cannot be interpreted as conclusive evidence of the freezing potential of the Red Spanish pineapple grown in Puerto Rico. There is a strong indication, however, that the frozen Red Spanish pineapple suffers changes in quality to the extent that it is generally inferior to the canned product. A frozen product of acceptable quality can be prepared by blanching the fruit to inactivate the enzyme system and packing in 30-40 Brix sirup with ascorbic acid added as an antioxidant. Because juice leaks during blanching, it seems advisable to blanch the fruit in the same sirup to be used as a packing medium.

\section{RESUMEN}

Cuando rebanadas de piña de las variedades Española Roja y Cayena Lisa escaldadas al vapor para inactivarles la bromelina y la peroxidasa se envasaron al vacío sin sirope 
en bolsas de Cryovac desarrollaron sabores extraños pronunciados durante su almacenamiento a $-10^{\circ} \mathrm{F}$. $\left(-23.3^{\circ} \mathrm{C}\right.$.).

La variedad Española Roja envasada en siropes de azúcar simple de 30 a $40^{\circ} \mathrm{F}$.y congelada a -40 en bolsas plásticas no cambió apreciablemente en calidad almacenada a $-10^{\circ}$ F. durante 280 días. La inactivación del sistema enzimático escaldando las rebanadas al vapor o calentándolas en sirope a $195^{\circ} \mathrm{F}$. $\left(90.5^{\circ} \mathrm{C}\right.$.) por 5 minutos mejoró levemente la calidad del producto congelado. La calidad del producto congelado también mejoró algo añadiendo al sirope entre 100 a $400 \mathrm{mg}$. de ácido ascórbico por cada libra (228-880 mg./kg.) de producto final.

Aunque en ocasiones la calidad del producto congelado era baja, los estudios de varias temporadas de cosecha tienden a indicar que la variedad Española Roja producida en Puerto Rico puede congelarse satisfactoriamente si se envasa en sirope, después de inactivarle el sistema enzimático.

\section{LITERATURE CITED}

1. Balls, A. K., and Hoover, S. R., The milk clotting action of papain, J. Biol. Chem. 121: 737-45, 1937.

2. Ballantine, R., Determination of ascorbic acid in citrus juices, Ind. Eng. Chem., Anal. Ed. 13: 89-90, 1941.

3. Boyle, F. P., and Wolford, E. R., The preparation for freezing and freezing of fruits, in The Freezing Preservation of Fruits, Vol. 3, p. 92, D. K. Tressler, W. Van Arsdel, and M. Copley, Ed, The Avi Publishing Co., Westport, Conn., 1968.

4. Methods of Analyses of the Association of Official Agricultural Chemists, 9th ed., $135,426,1960$.

5. Snedecor, G. W. and Cochran, W. G., Statistical Methods, 5th ed, The Iowa College Press, Ames, Iowa, 1959.

6. Tressler, D. K. and Evers, C. F., The Freezing Preservation of Foods, Vol. 1, 494, 546, The Avi Publishing Co., Westport, Conn., 1957. 